\title{
Effects of overfeeding antepartum and underfeeding postpartum on milk production and excretion of ketone bodies in milk
}

\author{
$P$ Miettinen \\ Department of Anatomy, University of Kuopio, SF 70211 Kuopio, Finland
}

Overfeeding before calving and underfeeding after calving predisposes bovine ketosis. The levels of ketone bodies in body fluids are widely used as indicators of energy balance after calving. However, there is no data available about the total amount of ketone bodies excreted in milk at different feeding levels.

Four control cows were fed according to the Finnish feeding standard grass silage, concentrate and hay. Six cows (test group) were overfed $(20 \%) 4$ weeks before calving and underfed $(25 \%)$ from 6 days postpartum up to 60 days to induce ketosis. For determination of milk components, milk samples were obtained twice a week from 6 days after calving. For determination of ketone bodies (acetone $=A C$, acetoacetate $=A A, B$ hydroxybutyrate $=\mathrm{HB}$ ), milk samples were obtained at the morning milking. The acetone content was determined by flow injection analysis with a FIAstar 5010/5020 analyzer, $A A$ and $H B$ according to Rajamäki and Rauramaa (1985, Meijerit Aika, 18, 9-15). The means, the milk yield and the amount of ketone bodies in milk from 6 to 120 days after calving were calculated with the KaleidaGraphTM integrate area program.
The means of ketones and daily milk yield was significantly lower, whereas fat content was higher in the test group than in the control group. Protein and lactose content was similar (3.14 $\pm 0.03 \%$ vs $3.13 \pm 0.03 \%$ and $4.62 \pm$ $0.02 \%$ vs $4.67 \pm 0.03 \%$ ). The total yields of milk (2862 kg vs $3278 \mathrm{~kg}$ ), of protein (89 kg vs $101 \mathrm{~kg}$ ) and of lactose (134 kg vs $152 \mathrm{~kg}$ ) were lower in the test group than in the control group, whereas the fat yield was similar in both groups (167 kg vs $166 \mathrm{~kg}$ ). The amount of acetone excreted in milk was four times higher in the test group than in the control group (3996 mmol vs $891 \mathrm{mmol}$ ), whereas the amount of AA ( $96 \mathrm{mmol}$ vs $57 \mathrm{mmol}$ ) and of HB was only slightly increased ( $324 \mathrm{mmol}$ vs 152 $\mathrm{mmol}$ ). The energy output was reduced by lowered milk production; a marked output of energy occurred due to excretion of ketones.

It is concluded that feeding level before and after calving plays a major role in bovine ketosis. There is a marked energy loss in ketotic cows, due to excretion of ketone bodies in milk. Since acetone can be regarded as waste for dairy cows, determination of milk acetone may be useful to evaluate the feeding level after calving.

\begin{tabular}{|c|c|c|c|c|c|}
\hline & $\begin{array}{c}\mathrm{AC} \\
(\mathrm{mMol})\end{array}$ & $\begin{array}{c}\mathrm{AA} \\
(\mathrm{mMol})\end{array}$ & $\begin{array}{c}\mathrm{HB} \\
(\mathrm{mMol})\end{array}$ & $\begin{array}{l}\text { Milk } \\
(\mathrm{kg})\end{array}$ & $\begin{array}{l}\text { Fat } \\
(\%)\end{array}$ \\
\hline Test & $0.69 \pm 0.19$ & $0.06 \pm 0.01$ & $0.18 \pm 0.03$ & $24.6 \pm 0.7$ & $6.09 \pm 0.10$ \\
\hline Control & $0.06 \pm 0.01^{b}$ & $0.02 \pm 0.01^{b}$ & $0.05 \pm 0.01$ & $28.9 \pm 0.8^{c}$ & $5.51 \pm 0.13^{c}$ \\
\hline
\end{tabular}

significance between the groups : $b=P<0.01, c=P<0.001$ 